ISSN: 1110-5623 (Print) - 2090-0570 (Online)

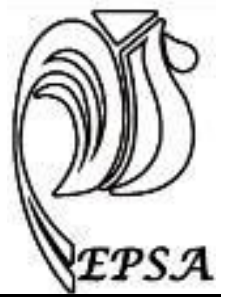

\title{
IMPACT OF FOOD INDUSTRY BYPRODUCTS AND WASTES ON BROILERS PERFORMANCE
}

Makled, M.N., H.H. Sharara, A.E.Galal., and A.M. Sayed

Poult. Prod. Dep., Fac. of Agric., Assiut Uni., Assiut 71515, Egypt;

Corresponding auther: A.E.Galal., E-mail: alialmaraghy@yahoo.com

Received: 12/02 /2019 Accepted: 24 /03 /2019

\begin{abstract}
There is a great shortage in poultry feed ingredients in Egypt; therefore, this study was carried out to evaluate the usage of some food industry byproducts and wastes in broiler diets. The effects of partial substitution of yellow corn (YC) with two levels of corn crunches waste (CCW), potato chips scraps (PCS), potato starchy waste (PSW), or sugar beet pulp (SBP) on growth performance, carcass traits and economic efficiency of broiler chicks were understudy. A total number of 297 unsexed one-day old ROSS broiler chicks were equally assigned into nine dietary groups (control and 8 treatments), each group of three even replicates. Two levels of each of the four byproducts partially replaced $5 \%$ or $10 \%$ of YC in the 8 treatments diets. Body weight (BW), body weight gain (BWG), feed consumption (FC), feed conversion ratio (FCR), and relative economic efficiency (REE) were estimated for the whole experimental period (6 weeks). At the end of the experiment, 6 birds from each group were sacrificed for evaluating carcass traits. The results revealed that BW and BWG at 6 wks of age of the groups received $5 \% \mathrm{CCW}$ or $10 \% \mathrm{PCS}$ in replace of $\mathrm{YC}$ were not significantly different from the control group; however, the lowest BW and BWG were detected for the groups received PSW or SBP. There were no significant differences in FC and FCR between all groups, except those received SBP which were worse. In regard to carcass traits, no significant differences were detected between treatments in breast \% and thigh; but eviscerated carcass weight, breast weight and thigh weight were significantly lower for the groups received SBP. The best net revenue was detected for the group received CCW instead of $5 \% \mathrm{YC}$, while the worst net revenue and REE were detected for SBP groups. In conclusion, corn crunches waste or potato chips scraps could replace $5 \%$ or $10 \%$ of YC; respectively, in broiler diets till 6 weeks of age without any adverse effect.
\end{abstract}

Keywords: Corn crunches waste-potato chips- starchy waste- sugar beet-broiler. 


\section{INTRODUCTION}

In poultry diets, corn represents almost $60 \%$ or more as compared to the other ingredients (Talha and Yaqoub, 2008). Meantime, corn is considered a crucial source for human nutrition in Egypt. Even though, this issue has formed a competition between human and poultry nutrition; however, human consumption has the priority to use this crop. This situation created a serious problem for the poultry industry (Hamzat et al., 2003).

From the nutritionists' point of view, the right way to solve this problem and to reduce the feeding costs is to get rid of the imported and expensive components such as corn and soybean meal and to identify some suitable byproducts and wastes as available and cheap alternatives for energy and protein feedstuffs. Mohdaly et al., (2010) reported that enormous amounts of byproducts are generated during the manufacturing of food products. Potato, corn and sugar beet processing industry for human consumption generates considerable quantities of byproducts and wastes which are rich in organic matter (Yamada et al., 2009). The utilization of these cheap abundant agro-industrial wastes for poultry nutrition has attracted some researchers' interest (Zand and Foroudi, 2011; and AbouSekken., et al., 2013).

Therefore, the objectives of this study were to study the effect of partial replacement of yellow corn with those byproducts and wastes in broilers diets on the performance of the chicks.

\section{MATERIALS AND METHODS}

The present work was conducted at the Poultry Research Farm, Faculty of Agriculture, Assiut University, to evaluate the effect of partial replacement of yellow corn (YC) (at two levels, 5\% and 10\%) with some byproducts and wastes in broilers diets on their performance from 1 day to 42 days of age. The wastes of potato industry used in this study were obtained from Chipsy Food Industries Co., S. A. E. at Assiut provinces, Egypt. These wastes of potato chips industry include potato chips scraps (PCS) and potato starchy waste (PSW). Besides, corn crunches waste (CCW) and sugar beet pulp (SBP) were obtained from corn "karate" factory and Sugar Beet Factory in Assiut and Menia province; respectively. A total number of 297 unsexed one-day old Ross broiler chicks were randomly divided into 9 groups (control and 8 treatments) of 3 replicates; each of 11 chicks. Birds of the different experimental groups had a similar average LBW at the start of the experiment. The birds were fed starter (0-2 wks), grower (3-4 wks) and finisher (5-6 wks) diets. The diets were formulated to contain $22 \% \mathrm{CP}$ and 3025 $\mathrm{kcal} \mathrm{ME} / \mathrm{kg}$ for the starter, $21 \% \mathrm{CP}$ and $3150 \mathrm{kcal} \mathrm{ME} / \mathrm{kg}$ for the grower, and 19\% $\mathrm{CP}$ and $3200 \mathrm{kcal} \mathrm{ME} / \mathrm{kg}$ for the finisher diets (Table 1, 2 and 3). Two levels of each of the four byproducts and wastes partially replaced $5 \%$ or $10 \%$ of $\mathrm{YC}$ in the 8 treatments diets. Chicks of all experimental treatments were kept under similar managerial and hygienic conditions. Chicks were brooded in a suitable floor pen covered with sawdust litter. The indoor temperature was kept at $33{ }^{\circ} \mathrm{C}$ for the first week of age and then was decreased three degrees weekly till $24{ }^{\circ} \mathrm{C}$ at three weeks of age and thereafter. The experimental starter, grower and finisher diets were weekly mixed and offered on ad-libtum basis in mash form. Clean water was available all the time, and an artificial lighting was provided continuously for 24 hrs / day. All chicks were vaccinated against the most popular diseases according to Assiut Research Poultry farm 


\section{Corn crunches waste-potato chips- starchy waste- sugar beet-broiler}

vaccination program. Chicks were individually weighed at start and weekly till the end of the experimental period (6 wks of age). Weighing birds was done in the early morning after fasting for $8 \mathrm{hrs}$. Body weight gain was calculated as the difference between the final and initial bird weight per week. Weight gain was calculated every week up to the 6th week as follows; $\mathrm{BWG}=(\mathrm{W} 1-\mathrm{W} 0) / \mathrm{T}$

Where, $\mathrm{W} 0=$ initial weight. $\mathrm{W} 1=$ final weight. $\mathrm{T}=$ period in days

Feed consumption was recorded weekly by applying the following formula: FC ( $\mathrm{g}$ / bird / week) = (supplied feed, $\mathrm{g}$ remaining feed, g) / (number of birds $\times$ number of days). FCR was calculated every week by dividing total feed consumed in a replicate by the total body weight gain of the birds of that replicate. According to the following formula: FCR $=$ Total FC $(\mathrm{g})$ per replicate during a certain period / Total BWG (g) for replicate during the same period. European broiler index (EBI) is one parameter of success maintenance of broiler chickens Van, (2003). In addition, it is widely used to describe the efficiency of broiler production and it can be calculated as follows: $\mathrm{EBI}=$ [viability $(\%) \times A D G(\mathrm{~g} /$ chick/d)] / (FCR $\times$ 10)

Where: Viability $(\%)=$ chicks remaining at the end of growth period (\%).

$\operatorname{ADG}(\mathrm{g} / \mathrm{chick} / \mathrm{d})=\mathrm{BWG} /$ days number of growth period.

At the end of the experiment; (42 day of age), 6 birds from each treatment ( 2 from each replicate around the average weight) were picked up to determine some carcass criteria. The birds were fasted for 12 hours before they were slaughtered. Thereafter, the following measurements were recorded: eviscerated carcass weight, breast weight, thigh weight and abdominal fat weight. Weights of breast and thigh were expressed relatively to eviscerated carcass weight, however; abdominal fat weight was expressed relatively to preslaughter live body weight.

To determine the EEF for broilers production, feeding cost was calculated based on the amount of $\mathrm{kg}$ feed consumed per bird from starter, grower and finisher experimental diets multiplied by the costs of the respective diets. Also, the LBW of the same bird was multiplied by the selling price of $\mathrm{kg}$ of LBW (24 LE). It is worthy to note that the prices of the ingredients used in the present study in L.E. per ton (at the experimental time) were: yellow corn: 2295; corn crunches waste: 1550 ; potato chips scraps: 1550 ; potato starchy waste: 770; sugar beet pulp: 1650. The cost of veterinary services, housing and labor were not included as they were constant for all treatment groups.

\section{RESULTS AND DISCUSSION}

The obtained results of live body weights of broiler chicks received the different experimental diets are presented in Table 4. The results revealed highly significant differences between treatments $(\mathrm{P} \leq 0.01)$ from the first week of age till 6 weeks of age. It was proved that body weights of the broilers received $\mathrm{CCW}$ at $5 \%$ and PCS at $10 \%$ of yellow corn (YC) did not differ significantly from those of the control chicks from one-week old till 6-weeks old. The data also revealed that body weights of the broilers received SBP at 5\% or $10 \%$ of yellow corn decreased significantly compared with those of the control group since the first week of age till 6 weeks of age. Moreover, the averages LBW of the broilers received $\mathrm{CCW}$ at $10 \%$; PSW at $5 \%$ or PSW at $10 \%$ of yellow corn were not significantly different from their control from one week old till 3 weeks old; however, they were significantly lower 
Makled, M.N et al.

thereafter till 6 weeks of age. The same pattern was proved for the treatment that received PCS at 5\% of yellow corn till the fourth week of age and then significantly decreased as compared with the control group. In general, it is worthy to mention that the best LBW at 6 weeks of age was proved for the broilers received $\mathrm{CCW}$ at $5 \%$ of corn; however, the worst LBW at 6 weeks of age was recorded for the broilers received SBP at 5\% of yellow corn. According to our findings, Zand and Foroudi, (2011) reported that CCW had been included in grower and finisher diets at levels of 17,30 and $50 \%$, and found that the usage of CCW had a negative impact on broiler chicks' weight $(\mathrm{p}<0.05)$. Faddle, (2003) reported that birds fed 15\% PCS had surpassed all groups and gave the highest LBW values during the startinggrowing period. Also, during the finishing period, the birds fed 15 or $20 \%$ PCS gave the highest LBW values at 5, 6 and 7 weeks of age. In contrast to our findings, AbouSekken et al., (2013) reported that chicks fed diets containing 3\% dietary SBP recorded significantly $(\mathrm{p} \leq 0.05)$ the best performance of LBW during the grower period (11-24 days). Petteresson and Razdana., (1992) found that along the whole experimental period, LBW of broiler chickens was not significantly influenced by SBP.

\section{Body weight gain (BWG):}

Table 5 shows the results of body weight gain at different growth periods. It has been proved that the different treatments impacted significantly $(\mathrm{P} \leq 0.5)$ on body weight gain at the different growth periods (starter, grower, and finisher). is the results clearly showed that BWG during the overall experimental period of chicks received $\mathrm{CCW}$ at $5 \%$ of $\mathrm{YC}$ was the best followed by that of chicks received PCS at $10 \%$ of YC. However, the worst BWG at different periods of growth was recorded by those chicks fed SBP at 5\% followed by those fed PSW at 5\% of yellow corn. According to the literature, Zand and Foroudi, (2011) reported that corn crunches waste had reduced $(\mathrm{P}<0.05)$ weight gain of broiler chicks. Also, Rahnema et al., (2004) reported that inclusion of 5\% PCS in the diet resulted in insignificant increases in BWG. Faddle, (2003) reported that birds fed $15 \%$ PCS showed a significant increase $(\mathrm{P} \leq 0.05)$ in BWG at the whole starting-growing period, however, at the finishing period, birds fed 20\% PCS gave the heaviest BWG. AbouSekken et al., (2013) reported that groups fed diets containing 3\% dietary SBP recorded the best $(\mathrm{p} \leq 0.05) \quad$ BWG. However, Jimenez-Moreno et al., (2011) found that any increase in the level of fiber sources from 2.5 to $7.5 \%$ reduced linearly average daily gain from 1 to $6 \mathrm{~d}(\mathrm{P} \leq 0.01)$ and from 6 to $12 \mathrm{~d}$ of age. Consequently, from 1 to $18 \mathrm{~d}$ of age average daily gain tended to decline. The optimal fiber level for improved $F: G$ estimated by regression analysis was 2.2 and $2.6 \% \mathrm{CF}$ for diets containing SBP and oat hulls, respectively.

\section{Feed consumption (FC):}

Results in Table 6 represent the feed consumption at different growth periods. The effect of experimental treatments on feed consumption was significant through the starter and grower periods but not significant during the finisher period and overall period. The highest feed consumption was recorded for PSW at $10 \%$ of YC during starter period; and for SBP at $10 \%$ of YC during grower period. The highest numerical feed consumption value for the overall period was recorded for both CCW at 5\% of YC and for SBP at $10 \%$ of YC. Zand and Foroudi, (2011) reported that usage of $\mathrm{CCW}$ reduced feed 
Corn crunches waste-potato chips- starchy waste- sugar beet-broiler

consumption of broiler chicks. Faddle, (2003) reported that during the startinggrowing period, the birds fed 5 or $15 \%$ PCS had the highest FC, while during the overall period, the birds fed diets containing 5\% PCS had the highest FC value, while those fed $20 \%$ PCS had the lowest one. Also, AbouSekken et al., (2013) reported that groups fed diets containing 3\% dietary SBP recorded significantly higher FC. While Rahnema et al., (2004) stated that inclusion of 5\% PCS in the diet resulted in non-significant increases in feed intake. Van Wyhe et al., (2012) reported that the increase in feed intake seen at higher inclusion rates of PCS may be a result of increased palatability due to PCS. A study comparing the effect of potato chips scraps inclusion into the diets of broiler chicks did not have a significant effect on feed intake at $5 \%$ inclusion, but at $7.5 \%$ did result in a significant increase in feed intake (Rahnema et al., 2004). Petteresson and Razdana., (1992) found that FC of broiler chicken for the whole experimental period, was not significantly influenced by SBP.

\section{Feed conversion ratio (FCR):}

Table 7 represent the values of feed conversion ratio ratios of experimental treatments during different growth periods. The impact of treatments on FCR was not significant at starter and finisher periods. while it was significant during grower and overall periods. It can be detected that at the starter period, the group of chicks received PCS at 5\% of YC exhibited best FCR similar to that of the control group. The best FCR at the grower period was recorded for the chicks fed $\mathrm{CCW}$ at $5 \%$ of $\mathrm{YC}$, and for the broilers received PSW at $5 \%$ of YC. However, the worst FCR was recorded for SBP at $5 \%$ of
YC in starter and finisher periods, and for SBP at $10 \%$ of YC in grower period. It is worthy to mention that the FCR for the overall period did not differ significantly between control, CCW at $5 \%$ and $10 \%$, PCS at $5 \%$ and $10 \%$ and PSW at $5 \%$ of YC; however, it was higher and significantly different for PSW at $10 \%$, SBP at $5 \%$ and $10 \%$ as compared with the control group. In this respect, Zand and Foroudi, (2011) reported that usage of CCW in broiler chicks diet at levels of 17 and $35 \%$ increased feed conversion ratio and at level of $50 \%$, feed conversion ratio was significantly improved $(\mathrm{p}<0.05)$. Rahnema et al., (2004) found that broiler diets containing up to $7.5 \%$ potato chips scraps did not change feed conversion ratio. Petteresson and Razdana, (1992) found that the chickens received diets containing $2.3 \%$ sugar beet pulp generally had converted feed more efficiently at both day 14 and 21 than those fed the control diets or diets including 4.6 or $9.2 \%$ SBP. AbouSekken et al., (2013) reported that chicks fed diets containing 3\% SBP recorded significantly the best FCR.

\section{European broiler index (EBI):}

The calculated values of EBI for broiler growth performance are presented in Figure 1. The EBI is a complex concept taking in account the average daily body weight gain, the feed efficiency and the viability percentage all over the growth period. The better growth performance was detected for the control group since it acquired the higher EBI (278) value. The second order for EBI came for the group fed CCW at $5 \%$ of YC (266) and the third order was proved for the group fed PCS at $10 \%$ of YC (252). However, the other treatments showed a worse growth performance compared with the control group since their EBI ranged from 217 for PCS at $5 \%$ of YC down to 196.9 for SBP 
Makled, M.N et al.

at $10 \%$ of YC. The low EBI recorded for the treatments received PSW at $5 \%$ or $10 \%$ of YC may be explained by the low body weight gain due to the low digestibility of the potato raw starch. Moreover, the poor performance as indicated by the lowest EBI calculated for the treatments fed SBP at $5 \%$ or $10 \%$ of YC may be due to its higher contents of fibers. This hypothesis is supported by data from Weurding et al., (2001) who reported that raw potato starch was extremely slow and low digested. They found that this slow digestion was undoubtedly associated with the incomplete starch digestion in the birds. They reported that potato starch was digested more slowly than cereals starch. Dietary fiber has been considered as a diluent and as anti-nutritional

factor in poultry diets because of its negative effects on energy intake and nutrient digestibility. Rougière and Carré, (2010) observed that broiler performance was improved when $2.3 \%$ SBP was included in the diet but that a further increase to 4.6 or $9.2 \%$ had negative effects.

\section{Carcass parts:}

The results obtained for breast, thigh and abdominal fat as weights and as percentages of the live body weight are presented in Table 8.

The results revealed that the differences between treatments were significant in concern with weights of breast, thigh and abdominal fat. However, these differences were not significant in respect to percentages of breast and thigh, but significant for abdominal fat percentage. It is shown from table 8 that the highest weight of breast and legs were recorded for the treatments received $\mathrm{CCW}$ at $5 \%$ of YC or PCS at $10 \%$ of YC even they were not significantly different from their control group. All the other treatments recorded lower weights for both breast and thigh. It is also clear from the data that the lower weight and percent of abdominal fat was recorded for the treatments fed SBP at $5 \%$ or $10 \%$ of YC. Zand and Foroudi, (2011) reported that the usage of CCW induced negative effect on thigh weight, breast weight and abdominal fat, but had no effect on liver, heart and gastrointestinal tract. While, Faddle, (2003) reported that abdominal fat and liver \% of birds fed PCS were significantly higher; however, no significant differences were observed between treatments for heart, spleen and gizzard $\%$. AbouSekken et al., (2013) studied the carcass characteristics of broilers as affected by dietary SBP levels. Their results showed no significant differences between groups fed different dietary SBP levels, except the relative weight of gizzard and heart which was significantly increased with increase of SBP level. The same results had been obtained by Gonzalez- Alvarado et al., (2010) who indicated that inclusion of SBP in broiler diets till 42 days of age significantly increased gizzard weight. Moreover, liver weight was insignificantly lower than control. The same trend had been reported by Jimenez-Moreno et al., (2009).

\section{Economic efficiency:}

The result for economic evaluation of broiler performance at 6 weeks of age is summarized in Table 9. It should be pointed out that the economic efficiency values were calculated according to the prevailing market prices for feed ingredients and broiler live body weight at the time of the experimental period. It is quite reasonable from economic point of view to compare the compatibility and consistency between three criteria that already have been evaluated in this study, i.e, European broiler index, net revenue, 


\section{Corn crunches waste-potato chips- starchy waste- sugar beet-broiler}

and relative economic efficiency (Figure 1 and Table 9). The control group came in first order in regard to EBI and in second order in regard to net revenue or relative economic efficiency. The treatment received $\mathrm{CCW}$ at $5 \%$ of $\mathrm{YC}$ came in first order in regard to net revenue and in second order in regard to EBI and its REE was too close to the control group (98.86 vs $100 \%)$. The treatment received PCS at $10 \%$ of $\mathrm{YC}$ came in the third order (after the control and $\mathrm{CCW}$ at $5 \%$ of $\mathrm{YC}$ groups) in regard to EBI, net revenue and REE. The treatment received PCS at 5\% of YC came in fourth order in concern to EBI and net revenue but in the fifth order in REE. The treatment received PSW at 5\% of YC came in the fifth order for EBI; in the sixth order for net revenue but too; close to the control in regard to REE; (100.11 vs $100 \%)$. It is worthy to mention that the advantage revealed for this group in regard to REE may be misleading since this result was mainly due to the significant decrease of feed intake during the overall experimental period but not for better growth. The other four treatments $(\mathrm{CCW}$ at $10 \%, \mathrm{PSW}$ at $10 \%, \mathrm{SBP}$ at $5 \%$ and SBP at $10 \%$ of $\mathrm{YC}$ ) were compatible in their order in regard to $\mathrm{EBI}$, net revenue or REE as they always came behind the control, $\mathrm{CCW}$ at $5 \%$, and PCS at $10 \%$ of YC. Therefore, it may be concluded that the treatments which received $\mathrm{CCW}$ at $5 \%$ or PCS at $10 \%$ of YC still could be competitive to the control group from the economic point of view. In this concern, Zand and Foroudi, (2011) reported that the corn crunches waste prices was nearly $75 \%$ of the corn prices, so they showed that the use of corn crunches waste had reduced feed costs and increased profits. Faddle, (2003) revealed that using PCS up to $20 \%$ to replace part of yellow corn in broiler chick diets had led to a lower feed cost and higher economic efficiency Van Wyhe et al., (2012) reported that the use of PCS may reduce the overall feed costs. AbouSekken, (2013) reported that increasing dietary SBP up to $3 \%$ had increased the economic efficiency. 
Makled, M.N et al.

Table (1):Composition and calculated analysis of the starter diets.

\begin{tabular}{|c|c|c|c|c|c|c|c|c|c|}
\hline Ingredient & control & $\begin{array}{l}5 \% \\
\mathrm{CCW}\end{array}$ & $\begin{array}{l}10 \% \\
\mathrm{CCW}\end{array}$ & $\begin{array}{l}5 \% \\
\text { PCS }\end{array}$ & $\begin{array}{l}10 \% \\
\text { PCS }\end{array}$ & $\begin{array}{l}5 \% \\
\text { PSW }\end{array}$ & $\begin{array}{l}10 \% \\
\text { PSW }\end{array}$ & $\begin{array}{l}5 \% \\
\text { SBP }\end{array}$ & $\begin{array}{l}10 \% \\
\text { SBP }\end{array}$ \\
\hline Yellow corn & 51.05 & 48.50 & 45.95 & 48.50 & 45.95 & 48.50 & 45.95 & 48.50 & 45.95 \\
\hline $\begin{array}{l}\text { Soya bean } \\
\text { meal } 44 \%\end{array}$ & 33.40 & 33.40 & 33.40 & 33.40 & 33.40 & 33.40 & 33.40 & 33.40 & 33.40 \\
\hline Concentrate ${ }^{1}$ & 10.00 & 10.00 & 10.00 & 10.00 & 10.00 & 10.00 & 10.00 & 10.00 & 10.00 \\
\hline Byproduct & 00.00 & 02.55 & 05.10 & 02.55 & 05.10 & 02.55 & 05.10 & 02.55 & 05.10 \\
\hline Sunflower Oil & 03.20 & 03.20 & 03.20 & 03.20 & 03.20 & 03.20 & 03.20 & 03.20 & 03.20 \\
\hline $\begin{array}{l}\text { Di- cal- } \\
\text { phosphate }\end{array}$ & 00.80 & 00.80 & 00.80 & 00.80 & 00.80 & 00.80 & 00.80 & 00.80 & 00.80 \\
\hline Limestone & 00.75 & 00.75 & 00.75 & 00.75 & 00.75 & 00.75 & 00.75 & 00.75 & 00.75 \\
\hline Vitamin $\operatorname{mix}^{2}$ & 00.25 & 00.25 & 00.25 & 00.25 & 00.25 & 00.25 & 00.25 & 00.25 & 00.25 \\
\hline Mineral mix $^{3}$ & 00.25 & 00.25 & 00.25 & 00.25 & 00.25 & 00.25 & 00.25 & 00.25 & 00.25 \\
\hline Salt $(\mathrm{NaCl})$ & 00.30 & 00.30 & 00.30 & 00.30 & 00.30 & 00.30 & 00.30 & 00.30 & 00.30 \\
\hline Total & 100 & 100 & 100 & 100 & 100 & 100 & 100 & 100 & 100 \\
\hline & \multicolumn{9}{|c|}{ Calculated analysis $\%{ }^{4}$} \\
\hline AME(kcal/kg) & 3017 & 3035 & 3053 & 3045 & 3073 & 3026 & 3035 & 2960 & 2903 \\
\hline Crude protein & 22.05 & 22.10 & 22.15 & 22.10 & 22.15 & 21.91 & 21.77 & 22.18 & 22.32 \\
\hline Crude fiber & 03.69 & 3.69 & 3.69 & 3.72 & 3.75 & 3.63 & 3.58 & 4.33 & 4.98 \\
\hline Ether extract & 05.64 & 6.11 & 6.58 & 6.49 & 7.34 & 5.57 & 5.51 & 5.57 & 5.51 \\
\hline $\begin{array}{l}\text { Price } \\
\text { (LE/kgdiet) }\end{array}$ & 3.87 & 3.85 & 3.83 & 3.85 & 3.83 & 3.83 & 3.79 & 3.85 & 3.83 \\
\hline
\end{tabular}

1) Concentrate supplemented /kg; ME $2807 \mathrm{kcal}$, CP 52\%, EE 2.28\%, CF 1.29\%, Ca 4.22\%, Phos $2.77 \%$, argi $2.51 \%$,

lysine $2.51 \%$ and Methionine $2.02 \%$.

(2) Each $3 \mathrm{~kg}$ of vitamins mix contain: A, 1200000 IU; Vit D3, 300000 IU; Vit E, 700 mg; Vit K3, $500 \mathrm{mg}$; VitB1, 500

mg; VitB2, 200 mg; VitB6, 600 mg; VitB12, 3000 mg; Vit C 450 mg; Niacin, 3000 mg; Methionine, $300 \mathrm{mg}$; Choline

chloride, $10000 \mathrm{mg}$; Folic acid, $300 \mathrm{mg}$ biotin $600 \mathrm{mg}$; Pantothenic acid $670 \mathrm{mg}$; Magnesium sulfate, $3000 \mathrm{mg}$; Copper

sulfate, $3000 \mathrm{mg}$; Iron sulfate, 10000; Zinc sulfate, 1800; Cobalt sulfate $300 \mathrm{mcg}$.

(3) Each 1 kg mineral mix contain: Mn, 60000 mg; Zn, 50000 mg; Fe, 3000 mg; Cu, 4000 mg; I, 300 $\mathrm{mg}$; Se, $100 \mathrm{mg}$;

Co, $100 \mathrm{mg}$.

(4) According to NRC (1994) except the AME values of the tested ingredients which were calculated according to Fisher 
Corn crunches waste-potato chips- starchy waste- sugar beet-broiler

Table (2): Composition and calculated analysis of the grower diets.

\begin{tabular}{|c|c|c|c|c|c|c|c|c|c|}
\hline Ingredient & $\begin{array}{l}\text { contro } \\
1\end{array}$ & $\begin{array}{l}5 \% \\
\mathrm{CC} \\
W\end{array}$ & $\begin{array}{l}10 \% \\
\mathrm{CC} \\
\mathrm{W}\end{array}$ & $\begin{array}{l}5 \% \\
\text { PCS }\end{array}$ & $\begin{array}{l}10 \% \\
\text { PCS }\end{array}$ & $\begin{array}{l}5 \% \\
\text { PSW }\end{array}$ & $\begin{array}{l}10 \% \\
\text { PSW }\end{array}$ & $\begin{array}{l}5 \% \\
\text { SBP }\end{array}$ & $\begin{array}{l}10 \% \\
\text { SBP }\end{array}$ \\
\hline Yellow corn & 52.65 & 50.02 & 47.38 & $\begin{array}{l}50.0 \\
2\end{array}$ & $\begin{array}{l}47.3 \\
8\end{array}$ & $\begin{array}{l}50.0 \\
2\end{array}$ & $\begin{array}{l}47.3 \\
8\end{array}$ & $\begin{array}{l}50.0 \\
2\end{array}$ & $\begin{array}{l}47.3 \\
8\end{array}$ \\
\hline $\begin{array}{l}\text { Soya bean } \\
\text { meal, } 44 \%\end{array}$ & 30.60 & 30.60 & 30.60 & $\begin{array}{r}30.6 \\
0\end{array}$ & $\begin{array}{r}30.6 \\
0\end{array}$ & $\begin{array}{r}30.6 \\
0\end{array}$ & $\begin{array}{r}30.6 \\
0\end{array}$ & $\begin{array}{r}30.6 \\
0\end{array}$ & $\begin{array}{r}30.6 \\
0\end{array}$ \\
\hline Concentrate $^{1}$ & 10.00 & 10.00 & 10.00 & $\begin{array}{l}10.0 \\
0\end{array}$ & $\begin{array}{l}10.0 \\
0\end{array}$ & $\begin{array}{l}10.0 \\
0\end{array}$ & $\begin{array}{l}10.0 \\
0\end{array}$ & $\begin{array}{l}10.0 \\
0\end{array}$ & $\begin{array}{l}10.0 \\
0\end{array}$ \\
\hline Byproduct & 00.00 & 02.63 & 05.27 & $\begin{array}{l}02.6 \\
3\end{array}$ & $\begin{array}{l}05.2 \\
7\end{array}$ & $\begin{array}{l}02.6 \\
3\end{array}$ & $\begin{array}{l}05.2 \\
7\end{array}$ & $\begin{array}{l}02.6 \\
3\end{array}$ & $\begin{array}{l}05.2 \\
7\end{array}$ \\
\hline Sunflower Oil & 04.70 & 04.70 & 04.70 & $\begin{array}{r}04.7 \\
0\end{array}$ & $\begin{array}{r}04.7 \\
0\end{array}$ & $\begin{array}{r}04.7 \\
0\end{array}$ & $\begin{array}{r}04.7 \\
0\end{array}$ & $\begin{array}{r}04.7 \\
0\end{array}$ & $\begin{array}{r}04.7 \\
0\end{array}$ \\
\hline $\begin{array}{l}\text { Di- cal- } \\
\text { phosphate }\end{array}$ & 0.70 & 0.70 & 0.70 & 0.70 & 0.70 & 0.70 & 0.70 & 0.70 & 0.70 \\
\hline Limestone & 00.55 & 00.55 & 00.55 & $\begin{array}{r}00.5 \\
5\end{array}$ & $\begin{array}{r}00.5 \\
5\end{array}$ & $\begin{array}{r}00.5 \\
5\end{array}$ & $\begin{array}{r}00.5 \\
5\end{array}$ & $\begin{array}{r}00.5 \\
5\end{array}$ & $\begin{array}{r}00.5 \\
5\end{array}$ \\
\hline Vitamin $\operatorname{mix}^{2}$ & 00.25 & 00.25 & 00.25 & $\begin{array}{l}00.2 \\
5\end{array}$ & $\begin{array}{l}00.2 \\
5\end{array}$ & $\begin{array}{l}00.2 \\
5\end{array}$ & $\begin{array}{l}00.2 \\
5\end{array}$ & $\begin{array}{l}00.2 \\
5\end{array}$ & $\begin{array}{l}00.2 \\
5\end{array}$ \\
\hline Mineral $\operatorname{mix}^{3}$ & 00.25 & 00.25 & 00.25 & $\begin{array}{l}00.2 \\
5\end{array}$ & $\begin{array}{l}00.2 \\
5\end{array}$ & $\begin{array}{l}00.2 \\
5\end{array}$ & $\begin{array}{l}00.2 \\
5\end{array}$ & $\begin{array}{l}00.2 \\
5\end{array}$ & $\begin{array}{l}00.2 \\
5\end{array}$ \\
\hline $\begin{array}{l}\text { Salt }(\mathrm{NaCl}) \\
\text { Total }\end{array}$ & $\begin{array}{l}00.30 \\
100\end{array}$ & $\begin{array}{l}00.30 \\
100\end{array}$ & $\begin{array}{l}00.30 \\
100 \\
\end{array}$ & $\begin{array}{l}00.3 \\
0 \\
100 \\
\end{array}$ & $\begin{array}{l}00.3 \\
0 \\
100 \\
\end{array}$ & $\begin{array}{l}00.3 \\
0 \\
100 \\
\end{array}$ & $\begin{array}{l}00.3 \\
0 \\
100 \\
\end{array}$ & $\begin{array}{l}00.3 \\
0 \\
100\end{array}$ & $\begin{array}{l}00.3 \\
0 \\
100\end{array}$ \\
\hline & \multicolumn{9}{|c|}{ Calculated analysis $\%$} \\
\hline $\mathrm{AME}(\mathrm{kcal} / \mathrm{kg}$ & 3140 & 3159 & 3178 & 3169 & 3198 & 3149 & 3158 & 3081 & 3022 \\
\hline Crude protein & 21.02 & 21.07 & 21.13 & $\begin{array}{l}21.0 \\
7\end{array}$ & $\begin{array}{l}21.1 \\
3\end{array}$ & $\begin{array}{l}20.8 \\
8\end{array}$ & $\begin{array}{l}20.7 \\
3\end{array}$ & $\begin{array}{l}21.1 \\
6\end{array}$ & $\begin{array}{l}21.3 \\
0\end{array}$ \\
\hline Crude fiber & 3.52 & 3.52 & 3.52 & 3.55 & 3.58 & 3.40 & 3.41 & 4.18 & 4.85 \\
\hline Ether extract & 7.17 & 7.66 & 8.15 & 8.05 & 8.93 & 7.11 & 7.05 & 7.11 & 7.05 \\
\hline $\begin{array}{l}\text { Price } \\
\text { (LE/kgdiet) }\end{array}$ & 3.96 & 3.94 & 3.92 & 3.94 & 3.92 & 3.92 & 3.88 & 3.94 & 3.92 \\
\hline
\end{tabular}


Makled, M.N et al.

\begin{tabular}{|c|c|c|c|c|c|c|c|c|c|}
\hline Ingredient & contro & $\begin{array}{l}5 \% \\
\text { CC } \\
W\end{array}$ & $\begin{array}{l}10 \% \\
\mathrm{CC} \\
\mathrm{W} \\
\end{array}$ & $\begin{array}{l}5 \% \\
\text { PCS }\end{array}$ & $\begin{array}{l}10 \% \\
\text { PCS }\end{array}$ & $\begin{array}{l}5 \% \\
\text { PSW }\end{array}$ & $\begin{array}{l}10 \% \\
\text { PSW }\end{array}$ & $\begin{array}{l}5 \% \\
\text { SBP }\end{array}$ & $\begin{array}{l}10 \% \\
\text { SBP }\end{array}$ \\
\hline Yellow corn & 59.15 & 56.19 & 53.24 & $\begin{array}{l}56.1 \\
9\end{array}$ & $\begin{array}{l}53.2 \\
4\end{array}$ & $\begin{array}{l}56.1 \\
9\end{array}$ & $\begin{array}{l}53.2 \\
4\end{array}$ & $\begin{array}{l}56.1 \\
9\end{array}$ & $\begin{array}{l}53.2 \\
4\end{array}$ \\
\hline Soya bean & 24.50 & 24.50 & 24.50 & 24.5 & 24.5 & 24.5 & 24.5 & 24.5 & 24.5 \\
\hline meal, $44 \%$ & & & & & & 0 & & & 0 \\
\hline Concentrate $^{1}$ & 10.00 & 10.00 & 10.00 & $\begin{array}{l}10.0 \\
0\end{array}$ & $\begin{array}{l}10.0 \\
0\end{array}$ & $\begin{array}{l}10.0 \\
0\end{array}$ & $\begin{array}{l}10.0 \\
0\end{array}$ & $\begin{array}{l}10.0 \\
0\end{array}$ & $\begin{array}{l}10.0 \\
0\end{array}$ \\
\hline Byproduct & 00.00 & 02.96 & 05.91 & $\begin{array}{l}02.9 \\
6\end{array}$ & $\begin{array}{l}05.9 \\
1\end{array}$ & $\begin{array}{l}02.9 \\
6\end{array}$ & $\begin{array}{l}05.9 \\
1\end{array}$ & $\begin{array}{l}02.9 \\
6\end{array}$ & $\begin{array}{l}05.9 \\
1\end{array}$ \\
\hline Sunflower & 04.45 & 04.45 & 04.45 & 04.4 & 04.4 & 04.4 & 04.4 & 04.4 & 04.4 \\
\hline Oil & & & & 5 & 5 & 5 & 5 & 5 & 5 \\
\hline $\begin{array}{l}\text { Di- cal- } \\
\text { phosphate }\end{array}$ & 00.50 & 00.50 & 00.50 & $\begin{array}{r}00.5 \\
0\end{array}$ & $\begin{array}{r}00.5 \\
0\end{array}$ & $\begin{array}{r}00.5 \\
0\end{array}$ & $\begin{array}{r}00.5 \\
0\end{array}$ & $\begin{array}{r}00.5 \\
0\end{array}$ & $\begin{array}{r}00.5 \\
0\end{array}$ \\
\hline Limestone & 00.60 & 00.60 & 00.60 & 00.6 & 00.6 & 00.6 & 00.6 & 00.6 & 00.6 \\
\hline & & & & 0 & & 0 & 0 & 0 & 0 \\
\hline Vitamin $\operatorname{mix}^{2}$ & 00.25 & 00.25 & 00.25 & 00.2 & 00.2 & 00.2 & 00.2 & 00.2 & 00.2 \\
\hline Mineral $\operatorname{mix}^{3}$ & 00.25 & 00.25 & 00.25 & $\begin{array}{l}5 \\
00.2\end{array}$ & 00.2 & $\begin{array}{l}5 \\
00.2\end{array}$ & $\begin{array}{l}5 \\
00.2\end{array}$ & $\begin{array}{l}5 \\
00.2\end{array}$ & $\begin{array}{l}5 \\
00.2\end{array}$ \\
\hline & & & & 5 & & & & & \\
\hline Salt $(\mathrm{NaCl})$ & 00.30 & 00.30 & 00.30 & 00.3 & 00.3 & 00.3 & 00.3 & 00.3 & 00.3 \\
\hline & & & & 0 & 0 & 0 & 0 & 0 & 0 \\
\hline Total & 100 & 100 & 100 & 100 & 100 & 100 & 100 & 100 & 100 \\
\hline & \multicolumn{9}{|c|}{ Calculated analysis, $\%$} \\
\hline $\mathrm{AME}(\mathrm{kcal} / \mathrm{kg}$ & 3200 & 3221 & 3242 & 3232 & 3264 & 3210 & 3220 & 3134 & 3067 \\
\hline Crude protein & 18.97 & 19.03 & 19.09 & 19.0 & 19.0 & 18.8 & 18.6 & 19.1 & 19.2 \\
\hline & & & & 3 & 9 & 1 & 5 & 3 & 9 \\
\hline Crude fiber & 3.22 & 3.22 & 3.21 & 3.25 & 3.29 & 3.15 & 3.09 & 3.96 & 4.71 \\
\hline Ether extract & 7.12 & 7.67 & 8.22 & 8.11 & 9.10 & 7.05 & 6.68 & 7.05 & 6.68 \\
\hline $\begin{array}{l}\text { Price (LE/kg } \\
\text { diet) }\end{array}$ & 3.80 & 3.78 & 3.76 & 3.78 & 3.76 & 3.76 & 3.71 & 3.78 & 3.76 \\
\hline
\end{tabular}

Statistical analysis: The data collected were analyzed by analysis of variance (ANOVA) using general linear model procedure (GLM) of SAS software (SAS institute, 2009). Percentage values were transformed using arcsine before statistical analysis. Significant differences between treatments means were determined using Duncan multiple range test (Duncan, 1955).

The following model was used: Yijk $=\mathrm{M}+\mathrm{Ti}+\mathrm{Rj}+\mathrm{Ejjk}$

Where;

Yijk = observation

$\mathrm{M}=$ overall mean

$\mathrm{Ti}=$ treatment effect, $\mathrm{i}$ ( 1 to 9$)$

$\mathrm{Rj}=$ replicate effect, $\mathrm{j}(1-3)$

Eijk = random error 
Corn crunches waste-potato chips- starchy waste- sugar beet-broiler

Table (4):Live body weight (LBW) at different ages (g/b/wk) of broiler chicks fed the experimental diets $(\overline{\mathrm{X} \pm} \mathrm{SE})$

\begin{tabular}{|l|c|c|c|}
\hline \multirow{2}{*}{ Treatment } & \multicolumn{3}{|c|}{ Age } \\
\cline { 2 - 4 } & At hatch & Third wk & Sixth wk \\
\hline Control & $52.7 \pm 3.2$ & $720.8 \pm 82.9 \mathrm{ab}$ & $2074.4 \pm 391.8 \mathrm{a}$ \\
CCW 5\% & $53.0 \pm 3.1$ & $717.2 \pm 104.2 \mathrm{abc}$ & $2124.1 \pm 281.4 \mathrm{a}$ \\
CCW 10\% & $53.4 \pm 3.5$ & $686.7 \pm 96.1 \mathrm{bc}$ & $1884.5 \pm 229.7 \mathrm{bcd}$ \\
PCS 5\% & $53.2 \pm 3.2$ & $747.3 \pm 90.1 \mathrm{a}$ & $1912.3 \pm 256.9 \mathrm{bc}$ \\
PCS 10\% & $52.4 \pm 3.1$ & $716.7 \pm 86.0 \mathrm{abc}$ & $2027.2 \pm 296.1 \mathrm{ab}$ \\
PSW 5\% & $53.4 \pm 3.6$ & $688.0 \pm 113.9 \mathrm{bc}$ & $1812.2 \pm 300.9 \mathrm{~cd}$ \\
PSW 10\% & $52.6 \pm 3.7$ & $712.6 \pm 98.2 \mathrm{abc}$ & $1848.4 \pm 271.9 \mathrm{~cd}$ \\
SBP 5\% & $52.8 \pm 3.6$ & $670.8 \pm 114.6 \mathrm{bc}$ & $1734.6 \pm 295.8 \mathrm{~d}$ \\
SBP 10\% & $52.6 \pm 3.5$ & $665.3 \pm 62.0 \mathrm{c}$ & $1862.4 \pm 199.1 \mathrm{~cd}$ \\
Overall & $52.9 \pm 3.4$ & $702.5 \pm 95.5$ & $1921.0 \pm 286.6$ \\
Effect of treatment & $\mathrm{NS}^{1}$ & $* *$ & $* *$ \\
\hline
\end{tabular}

1 NS not significant, * Significant at $(\mathrm{P} \leq 0.05), * *$ Significant at $(\mathrm{P} \leq 0.01)$

$2 \mathrm{a}, \mathrm{b}, \mathrm{c}$ and $\mathrm{d}$ : means in the same column having different letters are significantly different at $(\mathrm{P} \leq 0.05)$.

Table (5): Body weight gain at different growth periods (g/bird) of broiler chicks fed the experimental diets $(\mathrm{X} \pm \mathrm{SE})$. $^{-}$

\begin{tabular}{|c|c|c|c|c|}
\hline \multirow[t]{2}{*}{ Treatment } & \multicolumn{4}{|c|}{ Periods } \\
\hline & $\begin{array}{l}\text { Starter (0- } 14 \\
\text { day) }\end{array}$ & $\begin{array}{l}\text { Grower (15-28 } \\
\text { day) }\end{array}$ & $\begin{array}{l}\text { Finisher } \\
\text { (29-42 day) }\end{array}$ & $\begin{array}{l}\text { Overall } \\
(0-42 \text { day })\end{array}$ \\
\hline Control & $\begin{array}{c}312.2 \pm 3.1 \\
\text { abc } 2\end{array}$ & $805.0 \pm 9.3 \mathrm{a}$ & $904.4 \pm 19.7 \mathrm{ab}$ & $2020.2 \pm 9.3 \mathrm{a}$ \\
\hline CCW 5\% & $301.0 \pm 4.8 \mathrm{abc}$ & $812.0 \pm 7.9 \mathrm{a}$ & $971.6 \pm 13.7 \mathrm{a}$ & $2070.6 \pm 6.7 \mathrm{a}$ \\
\hline CCW $10 \%$ & $303.8 \pm 4.4 \mathrm{abc}$ & $709.8 \pm 8.0 \mathrm{bcd}$ & $805.0 \pm 11.5 \mathrm{bc}$ & $1831.2 \pm 5.4 \mathrm{bcd}$ \\
\hline PCS 5\% & $319.2 \pm 4.2 \mathrm{ab}$ & $728.0 \pm 9.4 \mathrm{bc}$ & $805.0 \pm 11.9 \mathrm{bc}$ & $1860.6 \pm 6.1 \mathrm{bc}$ \\
\hline PCS $10 \%$ & $309.4 \pm 3.9 \mathrm{abc}$ & $770.0 \pm 9.1 \mathrm{ab}$ & $894.6 \pm 12.8 \mathrm{ab}$ & $1974.0 \pm 7.0 \mathrm{ab}$ \\
\hline PSW 5\% & $292.6 \pm 4.7 \mathrm{bc}$ & $686.0 \pm 8.9 \mathrm{ecd}$ & $754.6 \pm 15.3 \mathrm{c}$ & $1759.8 \pm 7.2 \mathrm{~cd}$ \\
\hline PSW $10 \%$ & $326.2 \pm 3.9 \mathrm{a}$ & $653.8 \pm 9.1 \mathrm{ed}$ & $814.8 \pm 11.9 \mathrm{bc}$ & $1797.6 \pm 6.5 \mathrm{~cd}$ \\
\hline SBP 5\% & $289.8 \pm 5.2 \mathrm{bc}$ & $642.6 \pm 6.9 \mathrm{e}$ & $747.6 \pm 16.6 \mathrm{c}$ & $1684.2 \pm 7.0 \mathrm{~d}$ \\
\hline SBP $10 \%$ & $282.8 \pm 2.7 \mathrm{c}$ & $651.0 \pm 6.2 \mathrm{ed}$ & $876.4 \pm 11.0 \mathrm{ab}$ & $1810.2 \pm 4.7 \mathrm{~cd}$ \\
\hline $\begin{array}{l}\text { Effect of } \\
\text { treatment }\end{array}$ & $*$ & $* *$ & $* *$ & \\
\hline
\end{tabular}

1 NS not significant, * Significant at $(\mathrm{P} \leq 0.05),{ }^{* *}$ Significant at $(\mathrm{P} \leq 0.01)$

$2 \mathrm{a}, \mathrm{b}, \mathrm{c}, \mathrm{d}$ and e: means in the same column having different letters are significantly different at $(\mathrm{P} \leq 0.05)$ 
Makled, M.N et al.

Table (6):Feed consumption of broiler chicks fed the experimental diets at different growth periods $(\overline{\mathrm{X}} \pm \mathrm{SE})$.

\begin{tabular}{|l|l|l|l|c|}
\hline Treatment & \multicolumn{4}{|c|}{ Feed consumption (g/bird) } \\
\cline { 2 - 5 } & $\begin{array}{l}\text { Starter } \\
\text { (0- 14 day) }\end{array}$ & $\begin{array}{l}\text { Grower } \\
\mathbf{( 1 5 - 2 8 ~ d a y )}\end{array}$ & $\begin{array}{l}\text { Finisher } \\
\mathbf{( 2 9 - 4 2} \text { day) }\end{array}$ & $\begin{array}{c}\text { Overall } \\
\mathbf{( 0 - 4 2} \text { day })\end{array}$ \\
\hline Control & $446.6 \pm 0.0 \mathrm{~b} 2$ & $1300.6 \pm 5.6 \mathrm{a}$ & $1730.4 \pm 14.2$ & $3477.6 \pm 5.7$ \\
CCW 5\% & $446.6 \pm 0.0 \mathrm{~b}$ & $1296.4 \pm 3.1 \mathrm{a}$ & $1867.6 \pm 18.9$ & $3612.0 \pm 7.2$ \\
CCW 10\% & $450.8 \pm 0.6 \mathrm{~b}$ & $1244.6 \pm 2.0 \mathrm{abc}$ & $1612.8 \pm 8.5$ & $3305.4 \pm 3.2$ \\
PCS 5\% & $456.4 \pm 1.3 \mathrm{~b}$ & $1269.8 \pm 0.9 \mathrm{abc}$ & $1600.2 \pm 0.8$ & $3326.4 \pm 0.7$ \\
PCS 10\% & $446.6 \pm 0.0 \mathrm{~b}$ & $1282.4 \pm 3.1 \mathrm{ab}$ & $1738.8 \pm 6.9$ & $3465.0 \pm 3.3$ \\
PSW 5\% & $446.6 \pm 0.0 \mathrm{~b}$ & $1187.2 \pm 4.2 \mathrm{c}$ & $1436.4 \pm 12.9$ & $3066.0 \pm 5.6$ \\
PSW 10\% & $499.8 \pm 1.0 \mathrm{a}$ & $1262.8 \pm 4.7 \mathrm{abc}$ & $1710.8 \pm 11.8$ & $3477.6 \pm 4.6$ \\
SBP 5\% & $460.6 \pm 0.8 \mathrm{~b}$ & $1198.4 \pm 2.3 \mathrm{bc}$ & $1605.8 \pm 16.0$ & $3267.6 \pm 6.1$ \\
SBP 10\% & $446.6 \pm 0.0 \mathrm{~b}$ & $1323.0 \pm 0.4 \mathrm{a}$ & $1843.8 \pm 5.7$ & $3612.0 \pm 1.8$ \\
Effect of & $* * 1$ & $*$ & $\mathrm{NS}$ & $\mathrm{NS}$ \\
treatment & & & & \\
\hline
\end{tabular}

1 NS not significant, $*$ Significant at $(\mathrm{P} \leq 0.05),{ }^{* *}$ Significant at $(\mathrm{P} \leq 0.01)$

$2 \mathrm{a}, \mathrm{b}$ and $\mathrm{c}$ : means in the same column having different letters are significantly different at $(\mathrm{P} \leq$ $0.05)$

Table (7):Feed conversion ratio at different growth periods of broiler chicks fed the experimental diets $(\overline{\mathrm{X}} \pm \mathrm{SE})$.

\begin{tabular}{|l|c|c|c|c|}
\hline \multirow{2}{*}{ Treatment } & \multicolumn{4}{|c|}{ Feed conversion ratio (g feed / g gain) } \\
\cline { 2 - 5 } & $\begin{array}{c}\text { Starter } \\
\text { (0- 14 day) }\end{array}$ & $\begin{array}{c}\text { Grower } \\
(\mathbf{1 5 - 2 8} \text { day })\end{array}$ & $\begin{array}{c}\text { Finisher } \\
(\mathbf{2 9 - 4 2} \text { day })\end{array}$ & $\begin{array}{c}\text { Overall } \\
\mathbf{( 0 - 4 2} \text { day })\end{array}$ \\
\hline Contro & $1.43 \pm 0.0$ & $1.62 \pm 0.1 \mathrm{de} 2$ & $1.94 \pm 0.2$ & $1.73 \pm 0.1 \mathrm{~b}$ \\
CCW 5\% & $1.48 \pm 0.0$ & $1.59 \pm 0.0 \mathrm{e}$ & $1.92 \pm 0.0$ & $1.74 \pm 0.0 \mathrm{~b}$ \\
CCW 10\% & $1.49 \pm 0.0$ & $1.76 \pm 0.1 \mathrm{dc}$ & $2.03 \pm 0.1$ & $1.81 \pm 0.1 \mathrm{~b}$ \\
PCS 5\% & $1.44 \pm 0.1$ & $1.76 \pm 0.1 \mathrm{dc}$ & $1.98 \pm 0.1$ & $1.79 \pm 0.0 \mathrm{~b}$ \\
PCS 10\% & $1.44 \pm 0.0$ & $1.66 \pm 0.0 \mathrm{de}$ & $1.94 \pm 0.1$ & $1.75 \pm 0.1 \mathrm{~b}$ \\
PSW 5\% & $1.54 \pm 0.2$ & $1.74 \pm 0.0 \mathrm{cde}$ & $1.91 \pm 0.1$ & $1.75 \pm 0.1 \mathrm{~b}$ \\
PSW 10\% & $1.53 \pm 0.0$ & $1.93 \pm 0.1 \mathrm{ab}$ & $2.09 \pm 0.1$ & $1.93 \pm 0.1 \mathrm{a}$ \\
SBP 5\% & $1.59 \pm 0.0$ & $1.87 \pm 0.1 \mathrm{bc}$ & $2.17 \pm 0.1$ & $1.95 \pm 0.1 \mathrm{a}$ \\
SBP 10\% & $1.58 \pm 0.0$ & $2.03 \pm 0.1 \mathrm{a}$ & $2.10 \pm 0.1$ & $1.99 \pm 0.0 \mathrm{a}$ \\
Effect of & $\mathrm{NS1}$ & $* *$ & $\mathrm{NS}$ & $* *$ \\
treatment & \multicolumn{5}{|c|}{} \\
\hline
\end{tabular}

1 NS not significant, ${ }^{*}$ Significant at $(\mathrm{P} \leq 0.05),{ }^{* *}$ Significant at $(\mathrm{P} \leq 0.01) 2 \mathrm{a}, \mathrm{b}, \mathrm{c}, \mathrm{d}$ and e: means in the same column having different letters are significantly different at $(\mathrm{P} \leq 0.05)$ 
Table (8): Carcass parts of broiler chicks fed the experimental diets $(\overline{\mathrm{X}} \pm \mathrm{SE}){ }^{-}$

\begin{tabular}{|c|c|c|c|c|c|c|c|}
\hline \multirow[t]{2}{*}{ Ingredient } & \multirow{2}{*}{$\begin{array}{l}\text { Eviscerated } \\
\text { carcass }(\mathrm{g})\end{array}$} & \multicolumn{2}{|c|}{ Breast1 } & \multicolumn{2}{|c|}{ Thigh ${ }^{1}$} & \multicolumn{2}{|c|}{ Abdominal Fat } \\
\hline & & (g) & $(\%)$ & (g) & $(\%)$ & (g) & $(\%)$ \\
\hline Control & $1497.5 \mathrm{a}$ & $503.5^{a 3}$ & 33.6 & $433.2 \mathrm{a}$ & 28.9 & $39.3 \mathrm{a}$ & $2.0 \mathrm{ab}$ \\
\hline CCW 5\% & $1525.3 \mathrm{a}$ & $511.5 \mathrm{a}$ & 33.4 & $458.5 \mathrm{a}$ & 30.1 & $39.7 \mathrm{a}$ & $1.9 \mathrm{abc}$ \\
\hline CCW10\% & $1298.3 \mathrm{cb}$ & $430.3 \mathrm{~b}$ & 33.2 & 388.8 bc & 30.0 & $30.5 \mathrm{abc}$ & $1.7 \mathrm{abcd}$ \\
\hline PCS 5\% & $1301.3 \mathrm{cb}$ & $429.2 \mathrm{~b}$ & 33.0 & $388.0 \mathrm{bc}$ & 29.9 & $27.2 \mathrm{bc}$ & $1.5 \mathrm{abcd}$ \\
\hline PCS $10 \%$ & $1411.0 \mathrm{ab}$ & $501.7 \mathrm{a}$ & 35.5 & $428.7 \mathrm{ab}$ & 30.4 & $37.0 \mathrm{ab}$ & $1.9 \mathrm{abc}$ \\
\hline PSW 5\% & $1301.7 \mathrm{cb}$ & $466.7 \mathrm{ab}$ & 35.8 & $384.0 \mathrm{c}$ & 29.5 & $23.2 \mathrm{c}$ & $1.3 \mathrm{bcd}$ \\
\hline PSW 10\% & $1265.8 \mathrm{c}$ & $425.2 \mathrm{~b}$ & 33.6 & $376.7 \mathrm{c}$ & 29.7 & $34.7 \mathrm{ab}$ & $2.0 \mathrm{a}$ \\
\hline SBP 5\% & $1235.8 \mathrm{c}$ & $415.5 b$ & 33.6 & $369.8 \mathrm{c}$ & 29.8 & $22.2 \mathrm{c}$ & $1.3 \mathrm{dc}$ \\
\hline SBP $10 \%$ & $1283.8 \mathrm{c}$ & $424.7 \mathrm{~b}$ & 33.2 & $384.0 \mathrm{c}$ & 29.9 & $20.7 \mathrm{c}$ & $1.2 \mathrm{~d}$ \\
\hline Overall & $11346.7 \pm 18.1$ & $\begin{array}{c}456.5 \pm 53 \\
.9\end{array}$ & $\begin{array}{c}33.9 \pm 2 . \\
9\end{array}$ & $401.3 \pm 34.0$ & $29.8 \pm 1.5$ & $30.5 \pm 8.9$ & $1.7 \pm 0.5$ \\
\hline $\begin{array}{l}\text { Effect of } \\
\text { treatment }\end{array}$ & $* *$ & $* * 2$ & $(\%) \mathrm{NS}$ & $* * 2$ & NS & $* * 2$ & $* * 2$ \\
\hline
\end{tabular}

1 calculated as percentage from eviscerated carcass weight. 2 NS not significant, ** Significant at $(\mathrm{P} \leq 0.01)$.

$3 \mathrm{a}, \mathrm{b}, \mathrm{c}$ and, $\mathrm{d}:$ means in the same column having different letters are significantly different at $(\mathrm{P} \leq 0.05)$. 
Table (9) :Economic efficiency of the broiler chicks fed the experimental diets till 6 week of age.

\begin{tabular}{|c|c|c|c|c|c|c|c|c|c|c|c|c|c|c|}
\hline \multirow{2}{*}{$\begin{array}{l}\text { Treatmen } \\
\text { t }\end{array}$} & \multicolumn{2}{|c|}{ Starter } & \multicolumn{2}{|c|}{ Grower } & \multicolumn{2}{|c|}{ Finisher } & \multirow[b]{2}{*}{$\begin{array}{l}\text { Tota } \\
\text { l } \\
\text { feed } \\
\text { cost } \\
\text { (LE) }\end{array}$} & \multirow[b]{2}{*}{$\begin{array}{l}\text { LBW } \\
\text { (Kg/b } \\
) \\
42 \\
\text { day }\end{array}$} & \multirow{2}{*}{$\begin{array}{l}\text { Cost/k } \\
\text { g } \\
\text { BW }\end{array}$} & \multirow{2}{*}{$\begin{array}{l}\text { Price/k } \\
\text { g } \\
\text { Meat }\end{array}$} & \multicolumn{4}{|c|}{ Revenue } \\
\hline & $\begin{array}{l}\text { Pric } \\
\mathrm{e} \\
(\mathrm{LE}) \\
/ \mathrm{kg} \\
\text { feed }\end{array}$ & $\begin{array}{l}\text { Feed } \\
\text { intake } \\
\text { kg/ } \\
\text { perio } \\
\text { d } \\
\end{array}$ & $\begin{array}{l}\text { Pric } \\
\mathrm{e} \\
(\mathrm{LE}) \\
/ \mathbf{k g} \\
\text { feed }\end{array}$ & $\begin{array}{l}\text { Feed } \\
\text { intake } \\
\mathrm{kg} / \\
\text { perio } \\
\text { d }\end{array}$ & $\begin{array}{l}\text { Pric } \\
\mathrm{e} \\
(\mathrm{LE}) \\
/ \mathrm{kg} \\
\text { feed }\end{array}$ & $\begin{array}{l}\text { Feed } \\
\text { intake } \\
\text { kg/ } \\
\text { perio } \\
\text { d } \\
\end{array}$ & & & & & $\begin{array}{l}\text { Total } \\
\text { revenu } \\
\text { e }\end{array}$ & $\begin{array}{l}\text { Net } \\
\text { revenu } \\
\text { e }\end{array}$ & $\begin{array}{l}\text { Economi } \\
\text { c } \\
\text { efficiency }\end{array}$ & $\begin{array}{l}\text { Relative } \\
\text { economic } \\
\text { efficienc } \\
\mathbf{y}\end{array}$ \\
\hline Control & 3.87 & 0.447 & 3.96 & 1.301 & 3.80 & 1.730 & 13.46 & 2.07 & 6.50 & 24 & 49.68 & 36.22 & 269.1 & 100.00 \\
\hline CCW 5\% & 3.85 & 0.447 & 3.94 & 1.296 & 3.78 & 1.868 & 13.89 & 2.12 & 6.55 & 24 & 50.88 & 36.99 & 266.3 & 98.96 \\
\hline CCW $10 \%$ & 3.83 & 0.451 & 3.92 & 1.245 & 3.76 & 1.613 & 12.67 & 1.88 & 6.74 & 24 & 45.12 & 32.45 & 256.1 & 95.17 \\
\hline PCS 5\% & 3.85 & 0.456 & 3.94 & 1.270 & 3.78 & 1.600 & 12.81 & 1.91 & 6.71 & 24 & 45.84 & 33.03 & 257.8 & 95.80 \\
\hline PCS $10 \%$ & 3.83 & 0.447 & 3.92 & 1.282 & 3.76 & 1.739 & 13.28 & 2.03 & 6.54 & 24 & 48.72 & 35.44 & 266.9 & 99.18 \\
\hline PSW 5\% & 3.83 & 0.447 & 3.92 & 1.187 & 3.76 & 1.436 & 11.76 & 1.81 & 6.50 & 24 & 43.44 & 31.68 & 269.4 & 100.11 \\
\hline PSW $10 \%$ & 3.79 & 0.499 & 3.88 & 1.263 & 3.71 & 1.711 & 13.14 & 1.85 & 7.10 & 24 & 44.40 & 31.26 & 237.9 & 88.41 \\
\hline SBP 5\% & 3.85 & 0.461 & 3.94 & 1.198 & 3.78 & 1.606 & 12.57 & 1.73 & 7.27 & 24 & 41.52 & 28.95 & 230.3 & 85.58 \\
\hline SBP $10 \%$ & 3.83 & 0.447 & 3.92 & 1.323 & 3.76 & 1.844 & 13.83 & 1.86 & 7.44 & 24 & 44.64 & 30.81 & 222.8 & 82.79 \\
\hline
\end{tabular}

According to the local market price at the experimental time.

2 Assuming that the relative economic efficiency of the control diet equals 100 .

Total feed cost $=$ Feed intake $\mathrm{kg}(\text { starter })^{*}$ Price + Feed intake $\mathrm{kg}(\text { grower })^{*}$ Price + Feed intake kg (finisher $)^{*}$ Price

Cost $/ \mathrm{kg} \mathrm{BW}=$ Total feed cost/ LBW $(\mathrm{Kg} / \mathrm{b}) 42$ day

Total revenue $=\mathrm{LBW}(\mathrm{Kg} / \mathrm{b}) 42$ day* Price/kg (Meat)

Net revenue $=$ Total revenue- Total feed cost

Economic efficiency $=$ Net revenue $* 100 /$ Total feed cost

Relative economic efficiency $=$ Economic efficiency (treatment) $* 100 /$ Economic efficiency $($ control 


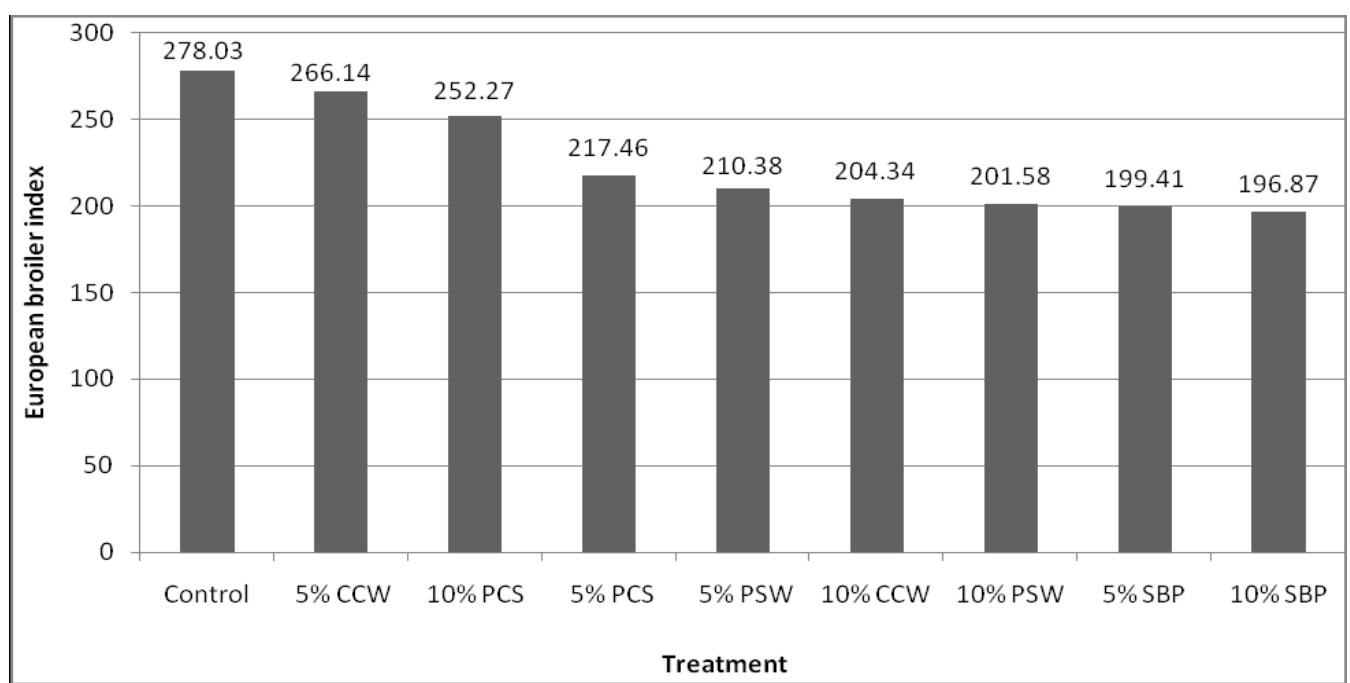

Figure (1) :The values of European broiler index (EBI) for broiler growth performance.

\section{REFERENCES}

\section{AbouSekken M. S., S. A. M. Shabban} and Randa A. Deifallah, 2013. Effect of enzyme supplementation on productive performance of broilers fed diets containing different levels of sugar beet pulp. Egyptian. J. Nutrition and Feeds, 16(2): special issue: 319336.

Duncan, D. B., 1955. Multiple ranges and multiple F test. Biometrics, 11:1- 42.

Faddle, A. A. A. M., 2003. Effect of broken potato chips as a substitute for yellow corn on broiler performance. Ph.D. Thesis, Faculty of Agric.,Fayoum, Cairo University., Egypt.

González-Alvarado, J. M., E. JiménezMoreno., D. González-Sánchez., R. Lázaro., and G.G. Mateos, 2010. Effect of inclusion of oat hulls and sugar beet pulp in the diet on productive performance and digestive traits of broilers from 1 to 42 days of age. Animal Feed Science and Technology., 162, 37-46.
Hamzat, R.A.S., A.K. Tiamiyu and A.M. Raji, 2003. Effect of dietary inclusion of kola pod husk (KPH) on growth performance of West African Dwarf (WAD) goats. Proc. 28th Annual Conf. Nig. Soc. For Anim. Prod. Ibadan, 2003: 21-273.

Jiménez-Moreno, E., J. M., GonzálezAlvarado., A. González-Serrano., R. Lázaro, and G.G. Mateos, 2009. Effect of dietary fiber and fat on performance and digestive traits of broilers from one to twenty-one days of age. Poult. Sci., 88: 2562-2574.

Jiménez-Moreno, E., M. Frikha., J. García, and G. G. Mateos, 2011. Effects of increasing levels of oat hulls or sugar beet pulp in the diet on growth performance, gastrointestinal tract development, and nutrient retention in broilers from one to eighteen days of age. Scholarone, 375 Greenbrier Drive, Charlottesville, VA, (434) 9644100.

Mohdaly, A. A. A., Sarhan, M. A., Smetanska, I., and A., Mahmoud, 2010. Antioxidant properties of various solvent extracts of potato peel, sugar beet pulp and sesame cake. Journal of 
Makled, M.N et al.

the Science of Food and Agriculture, 90, 218-226

Petteresson, D, and A, Razdana 1992. Effects of increasing levels of sugar beet pulp in broiler chicken diets on nutrient digestion and serum lipids. British Journal of Nutrition, 70, 127-137.

Rahnema, S., Lilburn, M. and J. Nixon,. 2004. Potato chips scraps in diets for broiler chicks. J. Appl. Anim. Res., 25: 14.

Rougière, N., and B. Carré, 2010. Comparison of gastrointestinal transit times between chickens from D + and D genetic lines selected for divergent digestion efficiency. Animal 4: 1861 1872.

SAS Institute, 2009. SAS user's guide: statistics. Version 9.th Edition. SAS institute Inc., Cary, NS.

Talha, E. E. A and M. Y. Yaqoub, 2008. Sunflower cake as substitute for groundnut cake in commercial broiler diets. Pak. J. Nutr., 7: 782-784.

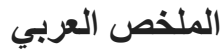

$$
\begin{aligned}
& \text { تقييم استخدام بعض المنتجات الثانوية والمخلفات من صناعة الأغذية في علائق كتاكيت التسمين. }
\end{aligned}
$$

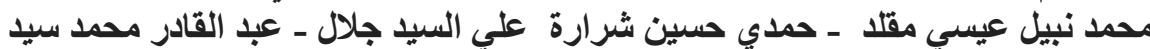

$$
\begin{aligned}
& \text { جامعة اسيوط كلية الزراعة الزئ }
\end{aligned}
$$

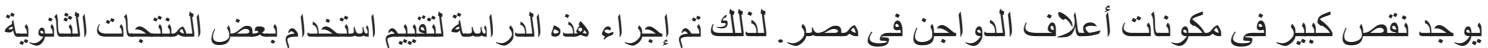

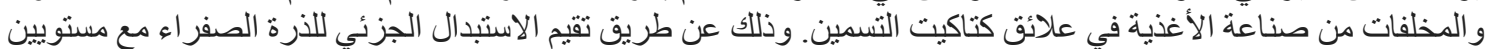

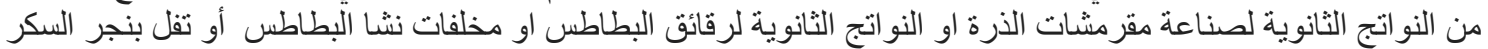

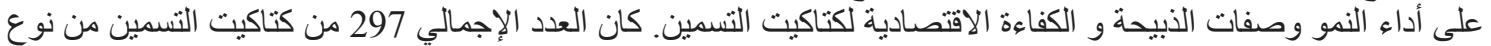

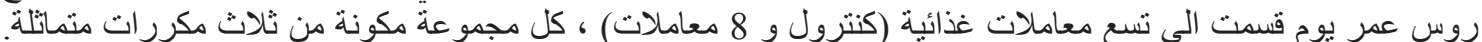

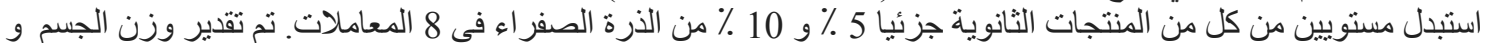

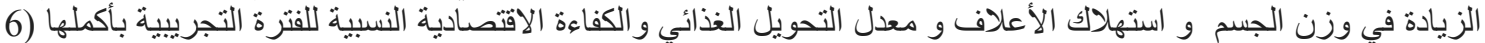

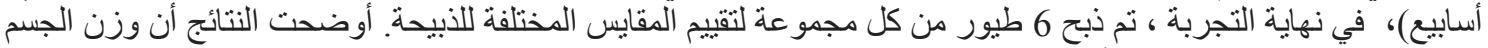

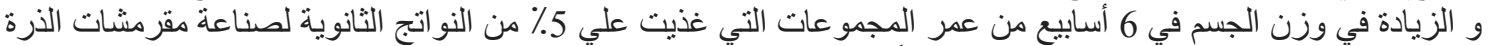

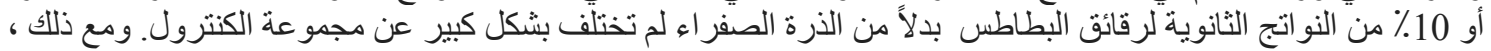

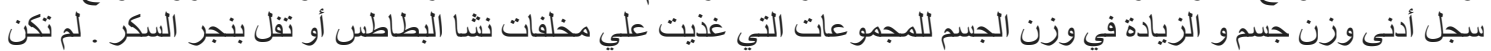

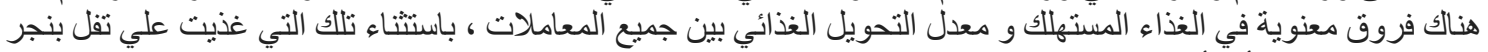

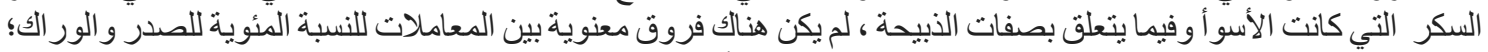

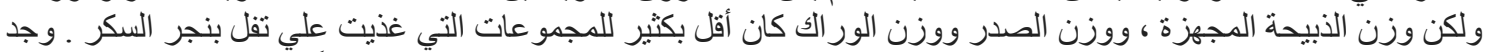

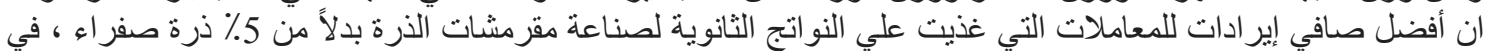

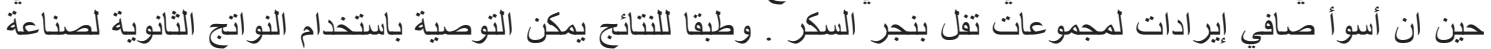

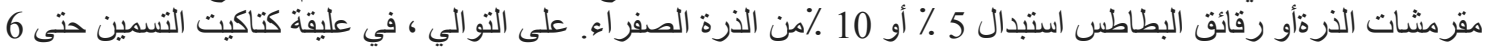
أسابيع من العمر دون أي تأثير سلبي. 